\title{
Pengaruh Kepuasan Pengguna Aplikasi Belanja Online Berbasis Mobile Menggunakan Metode EUCS
}

Effect of User Satisfaction of Mobile Based

Online Shopping Applications Using the EUCS Method

\author{
Indah Kurniasih $^{1}$, Desi Pibriana ${ }^{2}$ \\ 1,2 Program Studi Sistem Informasi, STMIK Global Informatika MDP \\ E-mail: ${ }^{1 *}$ indah.anita0110@mhs.mdp.ac.id, ${ }^{2}$ desi.pibriana@mdp.ac.id
}

\begin{abstract}
Abstrak
Internet merupakan salah satu media yang dapat digunakan sebagai media pemasaran suatu usaha. Internet tidak pernah luput dari perkembangan teknologi yang saat ini telah mengalami peningkatan yang sangat pesat, salah satunya perkembangan teknologi di bidang perdagangan. Dalam dunia perdagangan terdapat istilah e-commerce atau perdagangan secara elektronik. Pengguna pada dasarnya akan melakukan penilaian dalam setiap transaksi yang dilakukannya, baik itu transaksi konvensional maupun transaksi digital. Semakin baik layanan yang diberikan oleh penyedia jasa, maka semakin besar kemungkinan pengguna untuk kembali menggunakan layanan tersebut artinya pengguna merasa puas menggunakan aplikasi tersebut. Penelitian ini membahas mengenai kepuasan pengguna aplikasi belanja online PT. $\mathrm{ABC}$ International Indonesia. Analisis kepuasan pengguna diukur menggunakan metode End user computing satisfaction (EUCS) yang terdiri dari 5 faktor, yaitu: content, accuracy, format, ease of use, dan timeliness. Pengumpulan data dilakukan melalui kuesioner yang diisi oleh pengguna layanan aplikasi belanja online PT. ABC International Indonesia. Untuk mengolah data yang didapat dari hasil kuesioner menggunakan software SPSS. Dari analisis yang dilakukan, menunjukkan variabel content, accuracy, format, ease of use dan timeliness yang diajukan semua hipotesis diterima. Sedangkan berdasarkan uji F menunjukkan variabel content, accuracy, format, ease of use dan timeliness secara simultan berpengaruh terhadap kepuasan pengguna aplikasi belanja online.
\end{abstract}

Kata kunci: Aplikasi belanja online, mobile, EUCS, SPSS.

\begin{abstract}
The internet is one medium that can be used as a marketing medium for a business. The internet has never been spared from technological developments which at present have experienced a very rapid increase, one of which is technological developments in the field of commerce. In the world of commerce there is the term e-commerce or electronic commerce. The user basically will do an assessment in every transaction he does, both conventional transactions and digital transactions. The better the service provided by the service provider, the more likely the user to return to using the service means that the user is satisfied using the application. This study discusses the satisfaction of users of online shopping applications PT. $A B C$ International Indonesia. Analysis of user satisfaction is measured using the End user computing satisfaction (EUCS) method which consists of 5 factors, namely: content, accuracy, format, ease of use, and timeliness. Data collection was carried out through a questionnaire filled out by users of PT. ABC International Indonesia. To process the data obtained from the results of the questionnaire using SPSS software. From the analysis conducted, it shows that the content, accuracy, format, ease of use and timeliness variables proposed by all hypotheses are accepted. While based on the F test shows the content, accuracy, format, ease of use and
\end{abstract}


timeliness variables simultaneously affect the satisfaction of users of online shopping applications.

Keywords: Online shopping applications, mobile, EUCS, SPSS.

\section{PENDAHULUAN}

eknologi informasi berkembang dengan sangat pesat hampir pada seluruh aspek $\mathrm{T}$ kehidupan. Hal tersebut seiring dengan perkembangan internet yang memungkinkan penyebaran informasi terjadi dengan sangat cepat [1]. Indonesia merupakan negara dengan penggunaan internet terbesar ketiga di Asia setelah China dan India [2]. Pada 2019 Jumlah Pengguna Internet di Indonesia mencapai 103 juta orang, mengalahkan Jepang di posisi kelima seiring bertambahnya jumlah pengguna Internet secara perlahan [3]. Data tersebut mencerminkan bahwa minat masyarakat di Indonesia untuk menggunakan internet sangat tinggi, khususnya menggunakan perangkat mobile.

Internet tidak pernah luput dari perkembangan teknologi yang saat ini telah mengalami peningkatan yang sangat pesat. Perkembangan teknologi tidak hanya merambah disatu bidang saja, namun telah merambah disemua sektor kehidupan manusia. Perkembangan teknologi juga telah berkembang hingga ke bidang perdagangan. Dalam dunia perdagangan terdapat istilah $e$ commerce atau perdagangan secara elektronik. E-commerce merupakan salah satu hasil dari perkembangan teknologi internet. Pengertian e-commerce itu sendiri adalah suatu proses berbisnis dengan menggunakan teknologi elektronik yang menghubungkan antara perusahaan, konsumen, dan masyarakat dalam bentuk transaksi elektronik. Dengan demikian pada prinsipnya bisnis dengan e-commerce adalah bisnis tanpa warkat paperless trading [4].

Salah satu e-commerce yang ada di Indonesia adalah PT. ABC Internasional Indonesia. Pertamakali muncul di Indonesia pada tahun 2015. Pada tahun 2017, aplikasi belanja online ini mencatat 80 juta unduhan aplikasi dan lebih dari 180 juta produk aktif dari lebih dari empat juta wirausaha. Hingga saat ini, aplikasi belanja online berbasis mobile yang paling banyak digunakan adalah PT. ABC Internasional Indonesia [5]. Pelanggan pada dasarnya akan melakukan penilaian dalam setiap transaksi yang dilakukannya, baik itu transaksi konvensional maupun transaksi digital. Semakin baik layanan yang diberikan oleh penyedia jasa, maka semakin besar kemungkinan pelanggan untuk kembali menggunakan layanan tersebut [1].

Anderson dan Zeithaml (1984) serta Philips, Chang, dan Buzzel (1983), mengatakan bahwa keputusan pembelian pelanggan dipengaruhi oleh kualitas yang dianggap sebagai faktor keputusan pembelian yang paling penting [6]. Kepuasan pelanggan berkaitan dengan perbandingan antara persepsi pelanggan terkait layanan yang diterima dengan harapan pelanggan terhadap layanan yang diinginkannya. Kualitas layanan terbaik akan didapatkan ketika harapan pelanggan terlampaui, sementara di sisi lain kualitas layanan dianggap tidak dapat diterima ketika harapan tidak dipenuhi, serta kualitas layanan dianggap memuaskan ketika persepsi pelanggan sesuai dengan harapan [7]

Salah satu metode yang dapat digunakan untuk mengukur kepuasan pengguna terhadap penerapan suatu sistem informasi adalah model End user computing satisfaction (EUCS). End user computing satisfaction (EUCS) merupakan sebuah model untuk menghitung tingkat kepuasan pengguna akhir suatu sistem informasi. Pada model EUCS terdapat lima faktor yang

$\overline{\text { Indah, et., al (Pengaruh Kepuasan Pengguna Aplikasi Belanja Online Berbasis Mobile Menggunakan Metode EUCS: }}$ Effect of User Satisfaction of Mobile Based Online Shopping Applications Using The EUCS Method) 
dapat mempengaruhi kepuasan user terhadap penerapan suatu sistem informasi. Doll dan Torkzadeh menyatakan bahwa terdapat lima faktor yang perlu diperhatikan dalam mengembangkan sebuah sistem informasi adalah: isi (content), ketepatan (accuracy), bentuk (format), kemudahan penggunaan (ease of use), dan ketepatan waktu (timeliness) [8].

EUCS sebagai evaluasi keseluruhan sistem informasi yang digunakan oleh pengguna yang berhubungan dengan pengalaman pengguna sistem informasi tersebut [9]. Pengalaman pengguna sistem informasi diukur untuk mengetahui apakah sistem informasi yang digunakan telah efektif dan sesuai yang diinginkan oleh pengguna [10]. Model EUCS digunakan untuk menguji pengaruh dari konten, akurasi, format, kemudahan pengguna dan ketepatan waktu terhadap kepuasan pengguna. Kepuasan dapat diartikan sebagai kesesuaian sistem dengan ekspektasi penggunanya, dengan kata lain konsep kepuasan selaras dengan kesesuaian [11]. Sehingga, dalam penelitian ini peneliti ingin melihat bukti empiris serta menguji kesesuaian konten, akurasi, format, kemudahan pengguna, dan ketepatan waktu.

Dari banyaknya pengguna yang memakai aplikasi belanja online PT. ABC Internasional Indonesia mengindikasikan bahwa aplikasi belanja online tersebut memberikan aplikasi yang baik bagi pelanggan dari sisi content,accuracy,format,ease of use dan timeliness. dengan ini penulis akan menganalisis apakah responden telah merasa puas menggunakan aplikasi tersebut. Penelitian ini dilakukan dengan menganalisis kepuasan pengguna aplikasi belanja online PT. $\mathrm{ABC}$ Internasional Indonesia berbasis mobile dari versi lawas (2.1.68) hingga versi terbaru (2.57.13), dikarenakan PT. ABC Internasional Indonesia sejak awal mengusung sebagai market place berbasis mobile commerce atau mcommerce. Sehingga lebih banyak pengguna yang mengunduh aplikasi belanja online melalui smartphone. Tujuan lainnya yaitu untuk mengetahui pengaruh kepuasaan pengguna terhadap aplikasi belanja online berbasis mobile pada PT. ABC Internasional Indonesia menggunakan metode End user computing satisfaction (EUCS).

\section{METODE PENELITIAN}

\section{a. Metode Penelitian}

Dalam melakukan penelitian ini untuk mendapatkan data serta informasi adapun metode yang digunakan, yaitu dengan kuisioner dan studi literatur.

a. Kuesioner

Kuesioner merupakan teknik pengumpulan data yang dilakukan dengan cara memberi seperangkat pertanyaan atau pernyataan tertulis kepada responden untuk dijawab. Kuesioner juga cocok dugunakan bila jumlah responden cukup besar dan tersebar di wilayah yang luas. Kuesioner dapat berupa pertanyaan/ pernyataan tertutup atau terbuka dapat diberikan kepada responden secara langsung atau dikirimkan melalui pos, atau internet [12].

b. Studi Literatur

Studi literatur merupakan penelitian yang dilakukan oleh peneliti dengan mengumpulkan sejumlah buku buku, majalah yang berkaitan dengan masalah dan tujuan penelitian. Teknik ini dilakukan dengan tujuan untuk mengungkapkan berbagai teori-teori yang relevan dengan permasalahan yang sedang dihadapi/diteliti sebagai bahan rujukan dalam pembahasan hasil penelitian [13].

\subsection{Tahapan Penelitian}

Gambar 1 berikut adalah tahapan penelitian yang dilakukan dalam penelitian: 


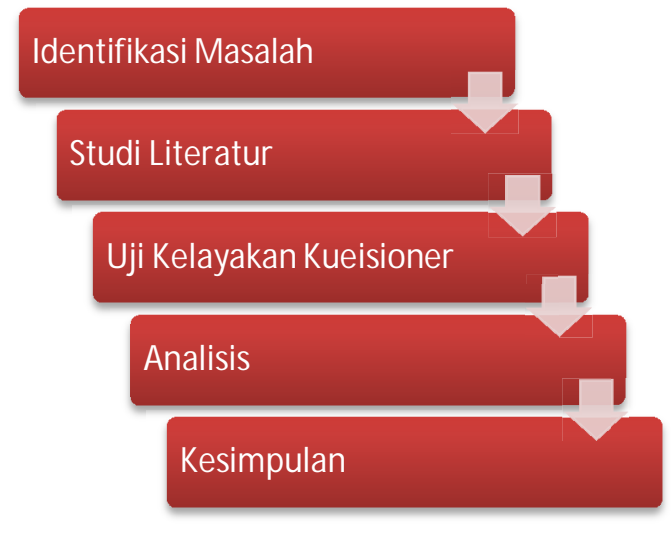

Gambar 1. Tahapan Penelitian

Langkah awal penelitian yaitu penulis memulai dengan mengidentifikasi masalah yang akan di analisis dalam penelitian ini. Kemudian melakukan studi literatur untuk mencari referensi yang berhubungan dengan penelitian yang akan dilakukan. Set elah mengidentifikasi populasi melakukan perhitungan sampel dengan rumus Rao Purba [14]. Selanjutnya menyusun kuesioner, uji kelayakan dan disebarkan kepada pengguna aplikasi belanja online. Setelah kuesioner terkumpul, selanjutnya dilakukan analisis data dengan melakukan Analisis Deskriptif, Pengujian Persyaratan Analisis, Uji validitas, Uji reliabilitas. Menentukan model Regresi Linier Berganda dan Uji Hipotesis dengan melakukan uji t dan uji $F$ menggunakan SPSS. Terakhir menginterpretasikan hasil yang didapat, dan menarik kesimpulan dari hasil penelitian.

\subsection{Populasi dan Sampel}

Populasi penelitian ini adalah pengguna aplikasi belanja online berbasis mobile. Jumlah populasi dalam penelitian ini tidak diketahui secara pasti. Adapun jumlah pengguna aplikasi belanja online didapatkan sebanyak 386 responden menggunakan rumus Rao purba [14].

Sampel adalah bagian dari jumlah dan karakteristik yang dimiliki oleh populasi. Bila populasi besar, dan peneliti tidak mungkin mempelajari semua yang ada pada populasi, misalnya karena keterbatasan dana, tenaga dan waktu, maka peneliti dapat menggunakan sampel yang diambil dari populasi itu. Apa yang dipelajari dari sampel itu, kesimpulannya akan dapat diberlakukan untuk populasi. Untuk itu sampel yang diambil dari populasi harus betulbetul representative (mewakili) [15].

\subsection{Penentuan Sampel}

Penentuan banyaknya sampel dalam penelitian ini menggunakan rumus Rao Purba [14]. Tingkat kesalahan (e) sebesar 5\% dan tingkat keyakinan sebesar 95\%.

$$
\begin{aligned}
& \mathrm{n}=\frac{Z^{2}}{4(m o e)^{2}} \\
& \mathrm{n}=\frac{(1,96)^{2}}{4(0,05 \%)^{2}}
\end{aligned}
$$

$\overline{\text { Indah, et., al (Pengaruh Kepuasan Pengguna Aplikasi Belanja Online Berbasis Mobile Menggunakan Metode EUCS: }}$ Effect of User Satisfaction of Mobile Based Online Shopping Applications Using The EUCS Method) 


$$
n=385,16 \approx \text { dibulatkan menjadi } 386
$$

Keterangan:

$\mathrm{n}=$ Ukuran sampel

$\mathrm{Z}=$ skor pada tingkat signifikan tertentu

Moe $=$ margin of error, tingkat kesalahan maksimum yang dapat ditoleransi

Tingkat kesalahan maksimum yang dapat ditoleransi pada penelitian ini ditetapkan sebesar 0,5 atau 5\% sehingga tingkat kepercayaan dalam penentuan sampel yang digunakan adalah $95 \%$ atau $\mathrm{z}=1,96$. Nilai tingkat keyakinan $95 \%$ atau $\mathrm{z}=1,96$ adalah tingkat keyakinan yang paling sering digunakan. Tingkat keyakinan $95 \%$ atau $\mathrm{z}=1,96$ memberikan keseimbangan antara presisi dan reliabilitas [16]. Perhitungan tersebut menunjukan bahwa sampel yang di ambil dalam penelitian ini adalah sebanyak 386 responden.

\subsection{Variabel Penelitian}

Berdasarkan studi literatur, diperoleh variabel dan indikator yang digunakan penelitian merujuk pada jurnal penelitian sebelumnya seperti pada Tabel 1.

Tabel 1. Variabel dan Indikator Penelitian

\begin{tabular}{|c|c|c|c|}
\hline Variabel & Kode & Indikator & Sumber \\
\hline \multirow{6}{*}{ Content $(\mathrm{X} 1)$} & $\mathrm{C} 1$ & $\begin{array}{l}\text { Menyediakan Informasi } \\
\text { yang tepat dan benar }\end{array}$ & \multirow{2}{*}{$\begin{array}{c}{[8][17]} \\
{[18]}\end{array}$} \\
\hline & $\mathrm{C} 2$ & $\begin{array}{l}\text { Isi dari informasi sesuai } \\
\text { kebutuhan }\end{array}$ & \\
\hline & $\mathrm{C} 3$ & $\begin{array}{l}\text { Isi dari informasi } \\
\text { lengkap serta mudah di } \\
\text { pahami }\end{array}$ & $\begin{array}{c}{[8][18]} \\
{[19]}\end{array}$ \\
\hline & $\mathrm{C} 4$ & $\begin{array}{c}\text { Informasi yang disajikan } \\
\text { menarik minat untuk } \\
\text { berbelanja }\end{array}$ & [18] \\
\hline & $\mathrm{C} 5$ & $\begin{array}{c}\text { Teks pada deskripsi } \\
\text { produk mudah di pahami } \\
\text { dan jelas sesuai dengan } \\
\text { produk }\end{array}$ & $\begin{array}{c}{[8][18]} \\
{[19]}\end{array}$ \\
\hline & C6 & $\begin{array}{c}\text { Informasi pada aplikasi } \\
\text { maupun pada deskripsi } \\
\text { produk memberikan } \\
\text { pengetahuan lebih } \\
\text { mengenai produk } \\
\text { tersebut }\end{array}$ & [17] \\
\hline \multirow{4}{*}{ Accuracy (X2) } & A1 & $\begin{array}{c}\text { Menampilkan informasi } \\
\text { produk secara benar dan } \\
\text { akurat }\end{array}$ & [8] [17] \\
\hline & $\mathrm{A} 2$ & $\begin{array}{c}\text { Fitur yang di klik selalu } \\
\text { menampilkan halaman } \\
\text { yang sesuai }\end{array}$ & [8] \\
\hline & A3 & Jarang terjadi error & [17] \\
\hline & $\mathrm{A} 4$ & Dapat memberikan dan & [8] [18] \\
\hline
\end{tabular}

Indah, et., al (Pengaruh Kepuasan Pengguna Aplikasi Belanja Online Berbasis Mobile Menggunakan Metode EUCS: Effect of User Satisfaction of Mobile Based Online Shopping Applications Using The EUCS Method) 


\begin{tabular}{|c|c|c|c|}
\hline & & $\begin{array}{c}\text { menampilkan informasi } \\
\text { yang sesuai dengan apa } \\
\text { yang saya cari }\end{array}$ & [19] \\
\hline \multirow{6}{*}{ Format(X3) } & F1 & Tampilan menu menarik & \\
\hline & $\mathrm{F} 2$ & Paduan warna serasi & \\
\hline & F3 & $\begin{array}{l}\text { Memiliki layout yang } \\
\text { memudahkan dalam } \\
\text { mencari produk }\end{array}$ & \\
\hline & $\mathrm{F} 4$ & $\begin{array}{l}\text { Struktur menu teratur } \\
\text { serta mudah di kenali }\end{array}$ & \\
\hline & F5 & $\begin{array}{l}\text { Tata letak menu dan } \\
\text { produk rapi serta teratur }\end{array}$ & [19] \\
\hline & F6 & $\begin{array}{c}\text { Standarisasi atau } \\
\text { keseragaman format } \\
\text { Jenis huruf yang normal, } \\
\text { jelas, dan terbaca }\end{array}$ & [17] \\
\hline \multirow{7}{*}{$\begin{array}{l}\text { Ease of use } \\
\quad \text { (X4) }\end{array}$} & E1 & User Friendly & \multirow{3}{*}{ [8] [18] } \\
\hline & E2 & $\begin{array}{c}\text { Memberikan pesan } \\
\text { kesalahan yang } \\
\text { informatif dan mudah } \\
\text { dipahami } \\
\end{array}$ & \\
\hline & E3 & $\begin{array}{l}\text { Dapat di akses dimana } \\
\text { saja dan kapan saja }\end{array}$ & \\
\hline & E4 & $\begin{array}{c}\text { Mudah dalam } \\
\text { menelusuri (navigasi) / } \\
\text { berpindah halaman }\end{array}$ & \multirow[t]{2}{*}{ [17] } \\
\hline & E5 & $\begin{array}{c}\text { Cara penggunaan yang } \\
\text { konsisten }\end{array}$ & \\
\hline & \multirow[t]{2}{*}{ E6 } & $\begin{array}{l}\text { Menyediakan tool tip } \\
\text { sebagai informasi } \\
\text { tambahan }\end{array}$ & \multirow[t]{2}{*}[18]{} \\
\hline & & $\begin{array}{c}\text { Memiliki fitur panduan } \\
\text { pengguna baru }\end{array}$ & \\
\hline \multirow{4}{*}{ Timeliness(X5) } & $\mathrm{T} 1$ & $\begin{array}{l}\text { Respons time dalam } \\
\text { menampilkan beranda } \\
\text { cukup cepat }\end{array}$ & \multirow{4}{*}{ [17] [19] } \\
\hline & $\mathrm{T} 2$ & $\begin{array}{l}\text { Menampilkan informasi } \\
\text { produk terbaru secara } \\
\text { cepat }\end{array}$ & \\
\hline & $\mathrm{T} 3$ & $\begin{array}{l}\text { Menampilkan deskripsi / } \\
\text { informasi produk secara } \\
\text { up to date }\end{array}$ & \\
\hline & $\mathrm{T} 4$ & $\begin{array}{c}\text { CS memberikan } \\
\text { tanggapan secara cepat } \\
\text { pengguna complaint }\end{array}$ & \\
\hline
\end{tabular}

Indah, et., al (Pengaruh Kepuasan Pengguna Aplikasi Belanja Online Berbasis Mobile Menggunakan Metode EUCS: Effect of User Satisfaction of Mobile Based Online Shopping Applications Using The EUCS Method) 


\begin{tabular}{|l|c|c|c|}
\hline & & mengenai produk & \\
\hline & Y1 & Sesuai kebutuhan & \\
\cline { 2 - 3 } & Y2 & $\begin{array}{c}\text { Dapat di andalkan } \\
\text { dimana saja dan kapan } \\
\text { saja }\end{array}$ & \\
\cline { 2 - 3 } & Yatisfaction(Y) & $\begin{array}{c}\text { Mempermudah dalam } \\
\text { mencari produk yang di } \\
\text { butuhkan }\end{array}$ & \multirow{2}{*}{ [8] } \\
\cline { 2 - 3 } & Y4 & $\begin{array}{c}\text { Harga dan kualitas } \\
\text { produk jauh lebih murah } \\
\text { dan baik kualitasanya } \\
\text { dibandingkan } \\
\text { ecommerce lain }\end{array}$ & \\
\hline
\end{tabular}

\section{4 Hipotesis Penelitian}

Penelitian ini menggunakan desain kausal yang bertujuan untuk menganalisis hubungan antara satu variabel dengan variabel lainnya. Desain kausal digunakan untuk menganalisis secara empiris variabel-variabel yang berpengaruh terhadap kepuasan pengguna (user satisfaction), yakni variabel isi (content), ketepatan (accuracy), bentuk (format), kemudahan penggunaan (ease of use), dan ketepatan waktu (timeliness) berdasarkan Model End user computing satisfaction yang dirumuskan oleh Doll \& Torkzadeh yang digunakan dalam penelitian [8]. Gambar 2 berikut adalah hipotesis penelitian berdasarkan model EUCS.

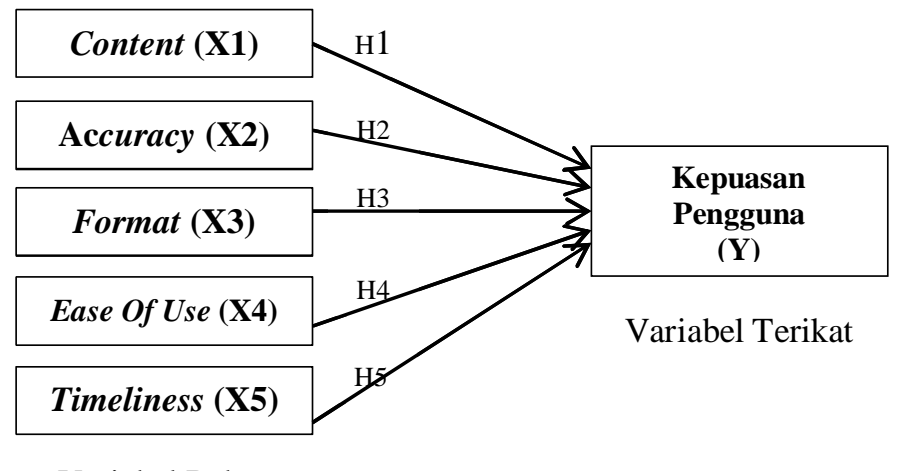

Variabel Bebas

Gambar 2. Model Penelitian

Untuk mengukur kepuasan user terhadap penerapan suatu sistem informasi dalam penelitian ini menggunakan model End User Computing Satisfaction (EUCS). Terdapat lima faktor yang dapat mempengaruhi kepuasan user terhadap penerapan suatu sistem. Faktor-faktor tersebut adalah: isi (Content), ketepatan (Accuracy), bentuk (Format), kemudahan penggunaan (Ease of use), dan ketepatan waktu (Timeliness). Sehingga, dirumuskan lima hipotesis dalam penelitian ini, yaitu:

$\mathrm{H} 1=$ Variabel content $(\mathrm{X} 1)$ berpengaruh terhadap tingkat kepuasan Pengguna $(\mathrm{Y})$.

$\mathrm{H} 2=$ Variabel accuracy $(\mathrm{X} 2)$ berpengaruh terhadap tingkat kepuasan pengguna $(\mathrm{Y})$.

$\mathrm{H} 3=$ Variabel format (X3) berpengaruh terhadap tingkat kepuasan pengguna (Y).

$\mathrm{H} 4=$ Variabel ease of use (X4) berpengaruh terhadap tingkat kepuasan pengguna (Y).

$\mathrm{H} 5=$ Variabel timeliness (X5) berpengaruh terhadap tingkat kepuasan pengguna (Y). 


\section{HASIL DAN PEMBAHASAN}

\subsection{Profil Responden}

Data responden dikelompokkan berdasarkan jenis kelamin, usia, pekerjaan, intensitas akses aplikasi belanja online perhari, pernah bertransaksi, dan intensitas transaksi. Gambar 3 merupakan profil responden berdasarkan jenis kelamin.

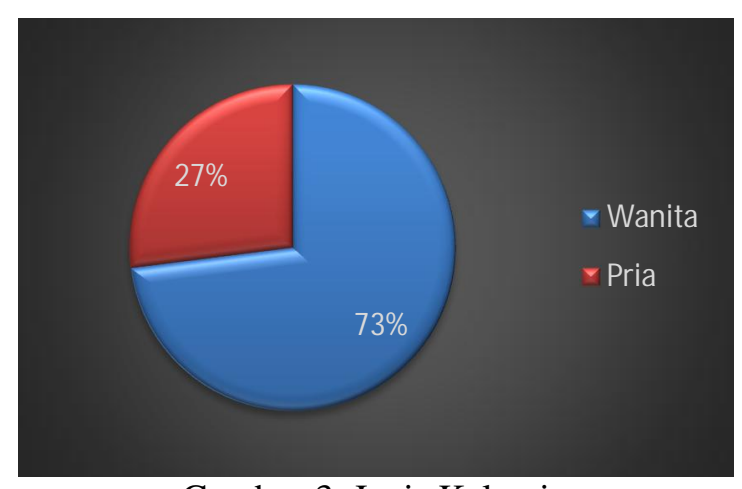

Gambar 3. Jenis Kelamin

Dari gambar 3, menunjukkan bahwa dari 386 data responden yang digunakan dalam analisis ini, sebagian besar didominasi oleh responden berjenis kelamin wanita sebanyak 256 orang dengan persentase $73 \%$, sedangkan sisanya merupakan responden berjenis kelamin pria sebanyak 130 orang dengan persentase $27 \%$. Gambar 4 adalah data responden berdasarkan usia.

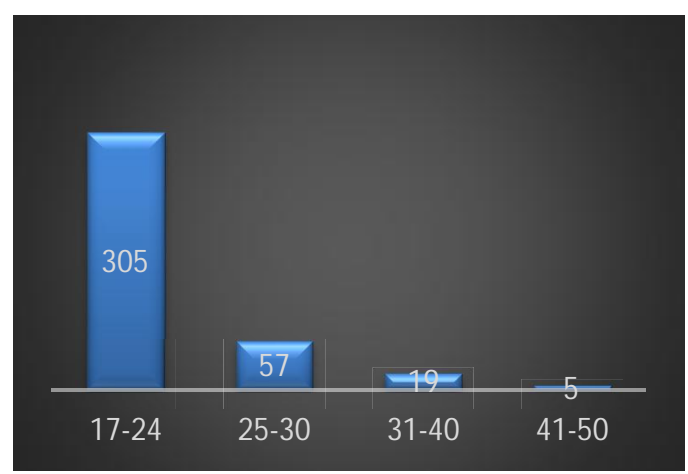

Gambar 4. Usia

Dari gambar 4, menunjukkan bahwa dari 386 data responden yang digunakan dalam analisis ini, sebagian besar didominasi oleh responden dengan rentang usia 17-24 tahun sebanyak 305 orang dengan persentase $79 \%$ selanjutnya diikuti dengan rentang usia responden 25-30 tahun sebanyak 57 orang dengan persentase 14.8\% kemudian 31-40 tahun sebanyak 19 orang dengan presentase 5\% dan 41- 50 tahun sebanyak 5 orang dengan presentase $1 \%$. Gambar 5 adalah data responden berdasarkan pekerjaan.

$\overline{\text { Indah, et., al (Pengaruh Kepuasan Pengguna Aplikasi Belanja Online Berbasis Mobile Menggunakan Metode EUCS: }}$ Effect of User Satisfaction of Mobile Based Online Shopping Applications Using The EUCS Method) 


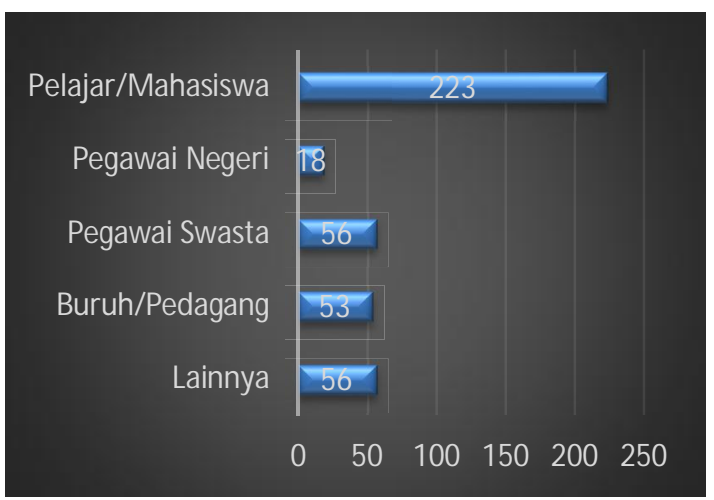

Gambar 5. Pekerjaan

Dari gambar 5 dapat diketahui bahwa pekerjaan responden paling banyak berasal dari pelajar/mahasiswa sebanyak 223 orang dengan persentase 58\% kemudian diikuti dengan pegawai negri sebanyak 18 orang dengan presentase 5\% selanjutnya pegawai swasta sebanyak 56 orang dengan 14\% kemudian buruh/pedagang sebanyak 33 orang dengan $9 \%$ dan pekerjaan lainnya sebanyak 56 orang dengan presentase 14\%. Gambar 6 data responden berdasarkan intensitas responden mengakses aplikasi belanja online perhari.

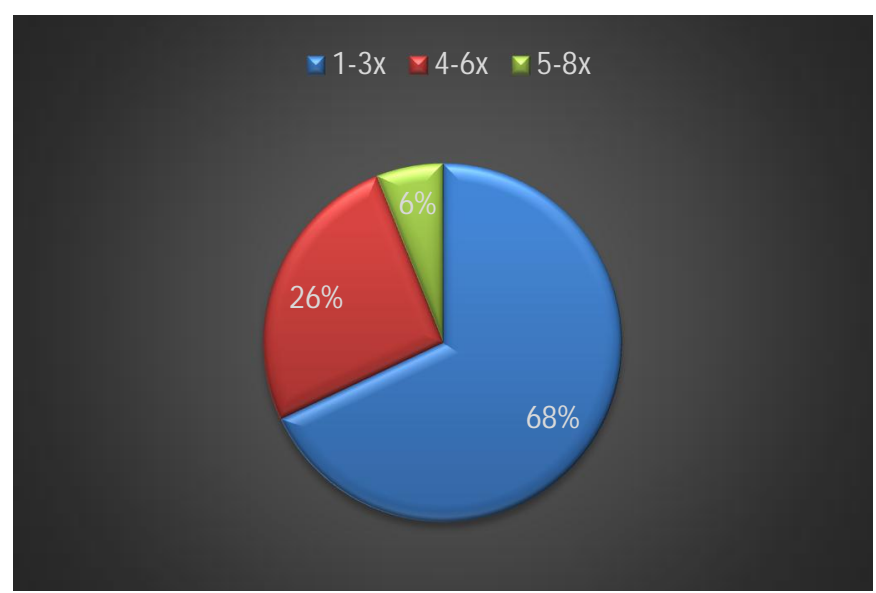

Gambar 6. Intensitas Akses Aplikasi belanja online

Dari gambar 6 dapat diketahui bahwa data responden yang digunakan pada analisis ini menunjukan responden paling banyak yang mengakses aplikasi belanja online sehari 1-3 kali berjumlah sebanyak 261 orang dengan persentase 68\%, kemudian diikuti dengan 4-6 kali dengan jumlah sebanyak 100 orang dengan presentase 26\% dan 5-8 kali dengan jumlah sebanyak 25 orang dengan presentase $6 \%$. Gambar 7 data responden berdasarkan berapa jumlah responden yang pernah bertransaksi di aplikasi belanja online dan yang tidak pernah bertransaksi. 


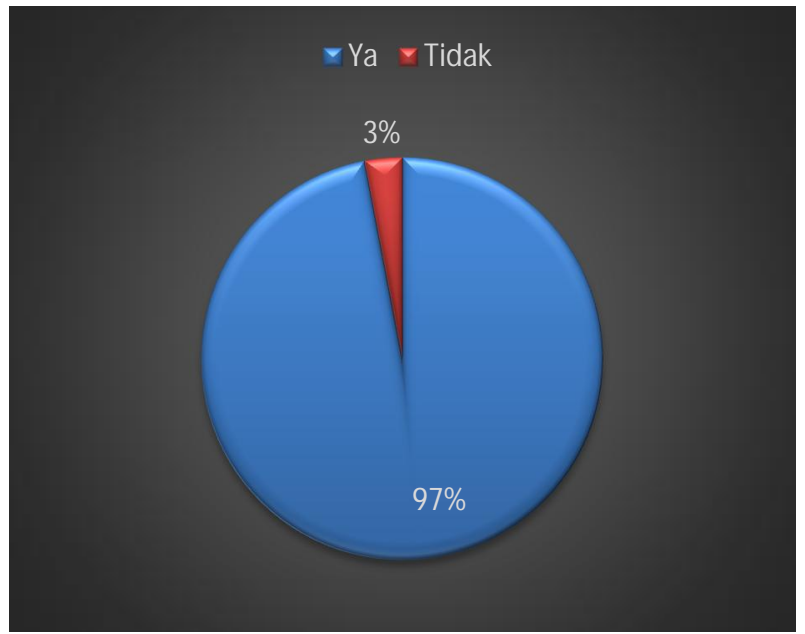

Gambar 7. Pernah Bertransaksi di aplikasi belanja online

Dari gambar 7 dapat diketahui bahwa responden yang pernah bertransaksi di aplikasi belanja online sebanyak 373 orang dengan persentase $97 \%$, sedangkan sisanya merupakan responden yang tidak pernah bertansaksi di aplikasi belanja online sebanyak 13 orang dengan persentase 3\%. Gambar 8 data responden berdasarkan intensitas responden bertransaksi di aplikasi belanja online.

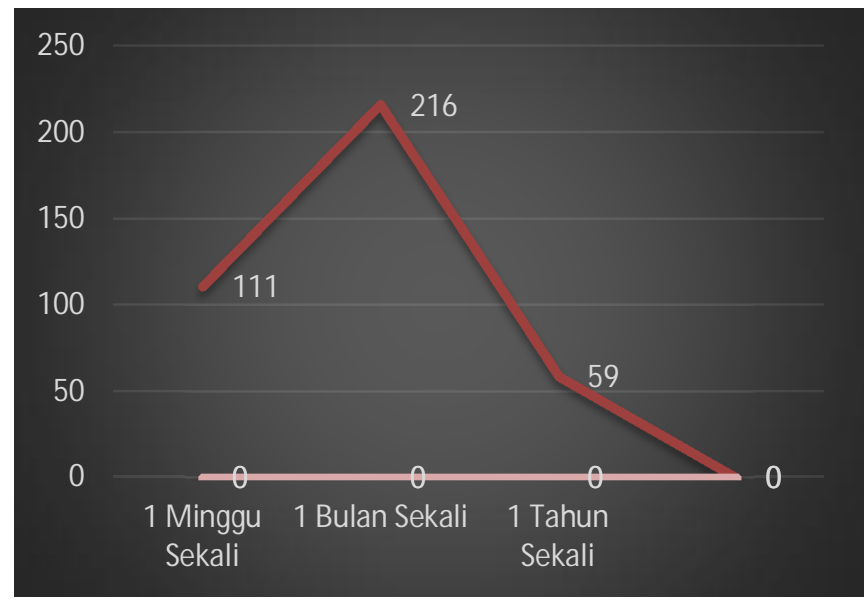

Gambar 8. Intensitas Bertransaksi

Dari gambar 8, maka dapat dilihat bahwa data responden yang digunakan pada analisis ini menunjukkan responden dengan intensitas bertransaksi sebanyak 1 bulan sekali berjumlah 216 orang dengan persentase 56\%, kemudian diikuti oleh 111 orang yang bertransaksi di aplikasi belanja online sebanyak 1 minggu sekali dengan presentase $29 \%$ dan yang terakhir responden yang bertransaksi di aplikasi belanja online sebanyak 1 tahun sekali yaitu berjumlah 59 orang dengan presentase $15 \%$.

Indah, et., al (Pengaruh Kepuasan Pengguna Aplikasi Belanja Online Berbasis Mobile Menggunakan Metode EUCS: Effect of User Satisfaction of Mobile Based Online Shopping Applications Using The EUCS Method) 


\section{2 Uji Validitas dan Reliabilitas}

Pengujian validitas dilakukan untuk memastikan seberapa baik instrumen digunakan untuk mengukur konsep yang seharusnya diukur, untuk menguji validitas konstruk yang dilakukan dengan cara mengorelasikan antara skor butir pertanyaan dengan skor totalnya [15]. Hasil dari perhitungan uji validitas ditunjukkan Tabel 2.

Tabel 2. Uji Validitas

\begin{tabular}{|c|c|c|c|c|}
\hline Indikator & rtabel & rhitung & Signifikan & Keterangan \\
\hline C1 & 0.0980 & 0.877 & 0,000 & Valid \\
\hline C2 & 0.0980 & 0.898 & 0,000 & Valid \\
\hline C3 & 0.0980 & 0.892 & 0,000 & Valid \\
\hline C4 & 0.0980 & 0.891 & 0,000 & Valid \\
\hline C5 & 0.0980 & 0.878 & 0,000 & Valid \\
\hline C6 & 0.0980 & 0.850 & 0,000 & Valid \\
\hline A1 & 0.0980 & 0.924 & 0,000 & Valid \\
\hline A2 & 0.0980 & 0.890 & 0,000 & Valid \\
\hline A3 & 0.0980 & 0.878 & 0,000 & Valid \\
\hline A4 & 0.0980 & 0.906 & 0,000 & Valid \\
\hline F1 & 0.0980 & 0.877 & 0,000 & Valid \\
\hline F2 & 0.0980 & 0.898 & 0,000 & Valid \\
\hline F3 & 0.0980 & 0.883 & 0,000 & Valid \\
\hline F4 & 0.0980 & 0.914 & 0,000 & Valid \\
\hline F5 & 0.0980 & 0.902 & 0,000 & Valid \\
\hline F6 & 0.0980 & 0.874 & 0,000 & Valid \\
\hline E1 & 0.0980 & 0.901 & 0,000 & Valid \\
\hline E2 & 0.0980 & 0.900 & 0,000 & Valid \\
\hline E3 & 0.0980 & 0.894 & 0,000 & Valid \\
\hline E4 & 0.0980 & 0.919 & 0,000 & Valid \\
\hline E5 & 0.0980 & 0.913 & 0,000 & Valid \\
\hline E6 & 0.0980 & 0.901 & 0,000 & Valid \\
\hline E7 & 0.0980 & 0.906 & 0,000 & Valid \\
\hline T1 & 0.0980 & 0.914 & 0,000 & Valid \\
\hline T2 & 0.0980 & 0.922 & 0,000 & Valid \\
\hline T3 & 0.0980 & 0.911 & 0,000 & Valid \\
\hline T4 & 0.0980 & 0.902 & 0,000 & Valid \\
\hline Y1 & 0.0980 & 0.878 & 0,000 & Valid \\
\hline Y2 & 0.0980 & 0.870 & 0,000 & Valid \\
\hline Y3 & 0.0980 & 0.888 & 0,000 & Valid \\
\hline Y4 & 0.0980 & 0.847 & 0,000 & Valid \\
\hline Y5 & 0.0980 & 0.892 & 0,000 & Valid \\
\hline & & & & \\
\hline
\end{tabular}

Dari tabel 2 hasil uji validitas diatas dengan menggunakan SPSS terhadap 386 data responden, dapat diambil kesimpulan bahwa semua item pernyataan tersebut memiliki nilai rhitung > rtabel dan nilai signifikansi p-value lebih kecil dari 0,05. Sehingga semua item pernyataan tersebut dapat digunakan dalam penelitian ini (valid). Reliabilitas berkenaan dengan tingkat ketetapan hasil pengukuran. Kuesioner dikatakan reliabel jika dapat memberikan hasil relative sama pada saat dilakukan pengukuran kembali pada objek yang berlainan pada waktu 
yang berbeda atau memberikan hasil yang tepat [15]. Hasil dari perhitungan uji reliabilitas dapat dilihat pada Tabel 3 .

Tabel 3. Uji Reliabilitas

\begin{tabular}{|c|c|c|c|}
\hline Variabel & $\begin{array}{c}\text { Cronbach } \\
\text { Alpha }\end{array}$ & $\begin{array}{c}\text { Standar } \\
\text { Reliabilitas }\end{array}$ & $\begin{array}{c}\text { Keterang } \\
\text { an }\end{array}$ \\
\hline Content & 0,942 & 0,7 & Reliabel \\
\hline Accuracy & 0,919 & 0,7 & Reliabel \\
\hline Format & 0,948 & 0,7 & Reliabel \\
\hline Ease of use & 0,963 & 0,7 & Reliabel \\
\hline Timeliness & 0,933 & 0,7 & Reliabel \\
\hline Satisfaction & 0,923 & 0,7 & Reliabel \\
\hline
\end{tabular}

Dari hasil uji reliabilitas, diperoleh nilai-nilai Cronbach Alpha dari semua variabel penelitian ini menunjukkan nilainya lebih besar dari nilai 0,7 maka semua item pernyataan dapat dikatakan reliabel, sehingga dapat digunakan dalam penelitian.

\subsection{Analisis Korelasi Parsial}

Analisis korelasi parsial ini digunakan untuk mengetahui kekuatan hubungan antara korelasi kedua variabel dimana variabel lainnya yang dianggap berpengaruh dikendalikan atau dibuat tetap (sebagai variabel kontrol). Karena variabel yang diteliti adalah data interval maka teknik statistik yang digunakan adalah Pearson Correlation Product Moment [15]. Tabel 4 adalah hasil analisis korelasi menggunkan SPSS.

Tabel 4. Analisis Korelasi

\begin{tabular}{|c|c|}
\hline Model & Satisfaction \\
\hline Content & 788 \\
\hline Accuracy & 747 \\
\hline Format & 675 \\
\hline Ease of use & 768 \\
\hline Timeliness & 731 \\
\hline
\end{tabular}

Berdasarkan hasil analisis Tabel 4 dan 5 dapat disimpulkan sebagai berikut:

1. Diperoleh nilai $r$ hitung content (X1) terhadap kepuasan pengguna $(\mathrm{Y})$ sebesar 0,788 > 0,1130 termasuk di interval koefisien 0,80 - 1,000 dengan tingkat hubungan sangat kuat dan nilai signifikansi variabel content sebesar $0,000<0,05$ sehingga terdapat korelasi antara variabel content dengan variabel satisfaction.

2. Diperoleh nilai $\mathrm{r}$ hitung accuracy (X2) terhadap kepuasan pengguna (Y) sebesar 0,747 > 0,1130 termasuk di interval koefisien 0,80 - 1,000 dengan tingkat hubungan sangat kuat dan nilai signifikansi variabel content sebesar $0,000<0,05$ sehingga terdapat korelasi antara variabel accuracy dengan variabel satisfaction.

3. Diperoleh nilai $r$ hitung format (X3) terhadap kepuasan pengguna (Y) sebesar 0,675 > 0,1130 termasuk di interval koefisien 0,80 - 1,000 dengan tingkat hubungan sangat kuat dan 
nilai signifikansi variabel content sebesar $0,000<0,05$ sehingga terdapat korelasi antara variabel format dengan variabel satisfaction.

4. Diperoleh nilai $r$ hitung ease of use (X4) terhadap kepuasan pengguna (Y) sebesar 0,768 > 0,1130 termasuk di interval koefisien 0,80 - 1,000 dengan tingkat hubungan sangat kuat dan nilai signifikansi variabel content sebesar $0,000<0,05$ sehingga terdapat korelasi antara variabel ease of use dengan variabel satisfaction.

5. Diperoleh nilai $r$ hitung timeliness (X5) terhadap kepuasan pengguna (Y) sebesar 0,731 > 0,1130 termasuk di interval koefisien 0,80 - 1,000 dengan tingkat hubungan sangat kuat dan nilai signifikansi variabel content sebesar $0,000<0,05$ sehingga terdapat korelasi antara variabel timeliness dengan variabel satisfaction.

\section{3 Analisis Regresi Linier Berganda}

Uji regresi berganda dalam penelitian ini dimaksudkan untuk melihat bagaimana pengaruh variabel independen terhadap dependen. Dengan menggunakan SPSS, regresi linier berganda didapatkan hasil Tabel 6 berikut:

Tabel 6. Regresi Linier Berganda

\begin{tabular}{|c|c|}
\hline Model & B \\
\hline 1 (Constant) & 4.760 \\
\hline Content & .244 \\
\hline Accuracy & .175 \\
\hline Format & .103 \\
\hline Ease of use & .111 \\
\hline Timeliness & .123 \\
\hline
\end{tabular}

Berdasarkan hasil analisis regresi menggunakan SPSS dapat dijelaskan melalui model regresi yang diperoleh sebagai berikut:

$$
\mathrm{Y}=4,760+0,244 \mathrm{X} 1+0,175 \mathrm{X} 2+0,103 \mathrm{X} 3+0,111 \mathrm{X} 4+0,123 \mathrm{X} 5
$$

1. Konstanta $=4,760$. Artinya jika variabel content, accuracy, format, ease of use dan timeliness dianggap sama dengan nol, maka variabel satisfaction mempunyai nilai 4,760.

2. Koefisien content $=0,244$. Artinya jika variabel content mengalami kenaikan sebesar 1 satuan sedangkan variabel lain dianggap konstan, maka variabel dependen yaitu satisfaction akan mengalami kenaikan sebesar 0,244.

3. Koefisien accuracy $=0,175$. Artinya jika variabel accuracy mengalami kenaikan sebesar 1 satuan sedangkan variabel lain dianggap konstan, maka variabel dependen yaitu satisfaction akan mengalami kenaikan sebesar 0,175.

4. Koefisien format $=0,103$. Artinya jika variabel format mengalami kenaikan sebesar 1 satuan sedangkan variabel lain dianggap konstan, maka variabel dependen yaitu satisfaction akan mengalami kenaikan sebesar 0,103 .

5. Koefisien ease of use $=0,111$. Artinya jika variabel ease of use mengalami kenaikan sebesar 1 satuan sedangkan variabel lain dianggap konstan, maka variabel dependen yaitu satisfaction akan mengalami kenaikan sebesar 0,111 .

6. Koefisien timeliness $=0,123$. Artinya jika variabel timeliness mengalami kenaikan sebesar 1 satuan sedangkan variabel lain dianggap konstan, maka variabel dependen yaitu satisfaction akan mengalami kenaikan sebesar 0,123 . 


\section{4 Uji Hipotesis}

\subsubsection{Uji t}

Uji t dilakukan untuk menguji tingkat signifikansi pengaruh variabel independen terhadap variabel dependen secara parsial. Tingkat signifikansi yang digunakan sebesar 5\%. Berdasarkan hasil analisis didapatkan hasil seperti pada Tabel 5 dan 6 yang menggunakan SPSS, hasil pengujian secara parsial adalah sebagai berikut:

1. Berdasarkan hasil uji t pada model regresi, diperoleh nilai t hitung 5,397 >t tabel 1,962 dan nilai signifikansi variabel content sebesar $0.000<0.05$ (taraf signifikansi 5\%). Artinya dapat disimpulkan bahwa secara parsial variabel content berpengaruh positif dan signifikan terhadap satisfaction.

2. Berdasarkan hasil uji t pada model regresi, diperoleh nilai t hitung sebesar 3,230 > t tabel 1,962 dan nilai signifikansi variabel accuracy sebesar $0.001<0.05$ (taraf signifikansi 5\%). Artinya dapat disimpulkan bahwa secara parsial variabel accuracy berpengaruh positif dan signifikan terhadap satisfaction.

3. Berdasarkan hasil uji $\mathrm{t}$ pada model regresi, diperoleh nilai t hitung sebesar 2,983 $>\mathrm{t}$ tabel 1,962 dan nilai signifikansi variabel format sebesar $0.003<0.05$ (taraf signifikansi 5\%). Artinya dapat disimpulkan bahwa secara parsial variabel format berpengaruh positif dan signifikan terhadap satisfaction.

4. Berdasarkan hasil uji $\mathrm{t}$ pada model regresi, diperoleh nilai $\mathrm{t}$ hitung sebesar 2,867 $>\mathrm{t}$ tabel 1,962 dan nilai signifikansi variabel ease of use sebesar $0.004<0.05$ (taraf signifikansi 5\%). Artinya dapat disimpulkan bahwa secara parsial variabel ease of use berpengaruh positif dan signifikan terhadap satisfaction.

5. Berdasarkan hasil uji t pada model regresi, diperoleh nilai t hitung sebesar 2,018 $>\mathrm{t}$ tabel 1,962 dan nilai signifikansi variabel timeliness sebesar $0.044<0.05$ (taraf signifikansi 5\%). Artinya dapat disimpulkan bahwa secara parsial variabel timeliness berpengaruh positif dan signifikan terhadap satisfaction.

\section{4.2 Uji F}

Uji $\mathrm{F}$ adalah untuk menunjukkan apakah variabel independen yang dimasukkan dalam model mempunyai pengaruh secara bersama-sama terhadap variabel dependen. Pengujian dilakukan dengan tingkat signifikansi $5 \%$ atau 0,05 . Berdasarkan hasil analisis didapatkan hasil sebagai berikut:

ANOVA $^{\mathrm{a}}$

\begin{tabular}{|c|c|c|c|c|c|c|}
\hline \multicolumn{2}{|c|}{ Model } & $\begin{array}{l}\text { Sum of } \\
\text { Squares }\end{array}$ & df & $\begin{array}{c}\text { Mean } \\
\text { Square }\end{array}$ & $F$ & Sig. \\
\hline \multirow[t]{3}{*}{1} & $\begin{array}{l}\text { Regressi } \\
\text { on }\end{array}$ & 3422.428 & 5 & 684.486 & $\begin{array}{r}169.39 \\
5\end{array}$ & $.000^{\circ}$ \\
\hline & Residual & 1535.490 & 380 & 4.041 & & \\
\hline & Total & 4957.917 & 385 & & & \\
\hline
\end{tabular}

a. Dependent Variable: Satisfaction

b. Predictors: (Constant), Timeliness, Format, Accuracy, Content, Ease Of Use

Gambar 9. Hasil Uji F

Indah, et., al (Pengaruh Kepuasan Pengguna Aplikasi Belanja Online Berbasis Mobile Menggunakan Metode EUCS: Effect of User Satisfaction of Mobile Based Online Shopping Applications Using The EUCS Method) 
Berdasarkan gambar 9 di atas dapat diperoleh nilai $\mathrm{F}$ hitung sebesar 169,395 dengan taraf signifikansi sebesar 0,000. Ini menunjukkan bahwa taraf signifikansi F hitung lebih kecil dari nilai tingkat signifikansi 0,05. Artinya bahwa variabel content, accuracy, format, ease of use dan timeliness secara bersama-sama mempunyai pengaruh yang positif dan signifikan terhadap satisfaction.

\section{5 Hasil Uji Koefisien Determinasi $\left(R^{2}\right)$}

Nilai koefisien determinasi ditunjukkan oleh nilai $\mathrm{R}^{2}$ dari model regresi digunakan untuk mengetahui besarnya variabilitas variabel dependen yang dapat dijelaskan oleh variabelvariabel bebasnya. Berdasarkan hasil analisis didapatkan hasil sebagai berikut:

Tabel 7. Hasil Uji Koefisien Determinasi

\begin{tabular}{|c|c|c|c|c|}
\hline Model & R & R Square & $\begin{array}{l}\text { Adjusted } \\
\text { R Square }\end{array}$ & $\begin{array}{c}\text { Std.Error Of } \\
\text { the Estimate }\end{array}$ \\
\hline 1 & .831 & .690 & .686 & 2.010 \\
\hline
\end{tabular}

a. Predictors: (Constant), Timeliness, Format, Accuracy, Content, Ease of use

Berdasarkan tabel 7 diatas menunjukkan bahwa nilai $\mathrm{R}^{2}$ sebesar 0,690 yang berarti bahwa variabilitas variabel satisfaction yang dapat dijelaskan oleh variabel content, accuracy, format, ease of use dan timeliness sebesar 69\%. Sedangkan sisanya sebesar 31\% dijelaskan oleh faktor lain yang tidak disertakan dalam penelitian ini.

\section{6 Pembahasan}

1. Variabel content berpengaruh terhadap tingkat kepuasan pengguna aplikasi belanja online.

Mengukur kepuasan pengguna ditinjau dari sisi content dari aplikasi belanja online. Variabel content memiliki hubungan yang signifikan terhadap kepuasan pengguna aplikasi belanja online, berdasarkan hasil dari uji t, diperoleh nilai t statistik sebesar 5,397 > dari t tabel 1,962 dan nilai signifikansi variabel content sebesar $0,000<0,05$. Artinya dapat disimpulkan bahwa variabel content berpengaruh positif dan signifikan terhadap satisfaction. Sehingga dapat disimpulkan bahwa hipotesis content (X1) dalam penelitian ini diterima.

2. Variabel accuracy berpengaruh terhadap tingkat kepuasan pengguna aplikasi belanja online.

Mengukur kepuasan pengguna dari sisi accuracy yang disediakan oleh aplikasi belanja online. Pada variabel accuracy hasil berdasarkan uji t, diperoleh nilai t statistik sebesar 3,230 $>$ dari t tabel 1,962 dan nilai signifikansi variabel accuracy sebesar 0,001 < 0,05. Artinya dapat disimpulkan bahwa variabel accuracy berpengaruh positif dan signifikan terhadap kepuasan pengguna. Sehingga dapat disimpulkan bahwa hipotesis accuracy (X2) dalam penelitian ini diterima.

3. Variabel format berpengaruh terhadap tingkat kepuasan pengguna aplikasi belanja online.

Mengukur kepuasan pengguna dari sisi format program aplikasi belanja online itu sendiri dimana variabel format berdasarkan hasil uji t, diperoleh nilai t statistik sebesar 2,983 > dari t tabel 1,962 dan nilai signifikansi variabel format sebesar $0,003<0,05$. Artinya dapat disimpulkan bahwa variabel format berpengaruh positif dan signifikan terhadap satisfaction. Sehingga dapat disimpulkan bahwa hipotesis format (X3) dalam penelitian ini diterima.

4. Variabel ease of use berpengaruh terhadap tingkat kepuasan pengguna aplikasi belanja online. 
Mengukur kepuasan pengguna dari sisi ease of use dalam menggunakan sistem seperti proses memasukan data, mengolah data, dan mencari informasi. Pada variabel ease of use berdasarkan hasil uji t, diperoleh nilai t statistik sebesar 2,867 > dari t tabel 1,962 dan nilai signifikansi variabel ease of use sebesar $0,004<0,05$. Artinya dapat disimpulkan bahwa variabel ease of use berpengaruh positif dan signifikan terhadap satisfaction. Sehingga dapat disimpulkan bahwa hipotesis ease of use (X4) dalam penelitian ini diterima.

5. Variabel timeliness berpengaruh terhadap tingkat kepuasan pengguna aplikasi belanja online.

Mengukur kepuasan pengguna dari sisi timeliness sistem dalam menyajikan atau menyediakan data dan informasi yang dibutuhkan oleh pengguna. Pada variabel timeliness berdasarkan hasil uji t, diperoleh nilai t statistik sebesar 2,018 > dari t tabel 1,962 dan nilai signifikansi variabel timeliness sebesar $0,044<0,05$. Artinya dapat disimpulkan bahwa variabel timeliness berpengaruh positif dan signifikan terhadap satisfaction. Sehingga dapat disimpulkan bahwa hipotesis timeliness (X5) dalam penelitian ini diterima.

\section{KESIMPULAN DAN SARAN}

Kesimpulan yang diperoleh dari hasil penelitian adalah sebagai berikut:

1. Berdasarkan hasil analisis data yang sudah dilakukan, dapat disimpulkan bahwa dari 5 hipotesis yang diajukan semua hipotesis tersebut diterima. Sesuai dengan rumusan permasalahan yang telah diuraikan pada latar belakang, terjawab bahwa hasil dari analisis secara parsial menunjukan bahwa variabel content (X1), variabel accuracy (X2), variabel format (X3), variabel ease of use (X4), variabel timeliness (X5) berpengaruh secara positif dan signifikan terhadap kepuasan pengguna aplikasi belanja online. Sedangkan berdasarkan hasil dari analisis secara simultan menunjukan bahwa variabel content (X1), variabel accuracy (X2), variabel format (X3), variabel ease of use (X4), variabel timeliness (X5) berpengaruh secara positif dan signifikan terhadap kepuasan pengguna aplikasi belanja online.

2. Hasil yang didapat dari nilai $\mathrm{F}$ hitung dan tingkat signifikan menunjukan variabel content, accuracy, format, ease of use dan timeliness secara simultan berpengaruh terhadap kepuasan pengguna aplikasi belanja online.

Adapun saran yang dapat diberikan untuk penelitian selanjutnya adalah:

1. Diharapkan dapat menggunakan metode yang berbeda agar bisa dibandingkan dengan penelitian yang sudah dilakukan sebelumnya, atau menggunakan metode yang sama namun dengan kasus yang berbeda dan dengan jumlah populasi yang lebih banyak.

2. Untuk penelitian selanjutnya dapat menggunakan teknik pengambilan sampling yang berbeda dari penelitian yang dilakukan ini dan menggunakan sampel dengan jumlah yang sudah diketahui jumlah pastinya. Karena mungkin dari teknik pengambilan sampling dan sampel yang sudah diketahui jumlahnya yang akan dilakukan dapat mempengaruhi hasil dari penelitian yang dilakukan.

Indah, et., al (Pengaruh Kepuasan Pengguna Aplikasi Belanja Online Berbasis Mobile Menggunakan Metode EUCS: Effect of User Satisfaction of Mobile Based Online Shopping Applications Using The EUCS Method) 


\section{DAFTAR PUSTAKA}

[1] Sihotang, F. P. 2019, Perbandingan Kualitas Layanan Dua Aplikasi Transportasi Online Menggunakan Metode Servqual, JATISI (Jurnal Teknik Informatika dan Sistem Informasi), 6(2), pp. 147-162. doi: 10.35957/jatisi.v6i2.190.

[2] Internet World Stats Usage and Population Statistics 2018, "Asia Internet Use, Population Data and Facebook Staistick - December 2017”, [Online], Available: https://www.internetworldstats.com/stats3.htm\#asia, [Accessed: 06-Aug-2019].

[3] Skipper 2019, Jumlah Pengguna Internet di Indonesia Tahun 2019.

[4] Munir Fuady. 2002, Pengantar Hukum Bisnis, PT. Citra Aditya Bakti, Bandung.

[5] Tay, Vivienne. 2017, Aplikasi Belanja Online Found to Be The Most Popular ECommerce Site for Indonesian Mothers, Marketing Interactive (dalam bahasa Inggris).

[6] U. Essays2017, Definition of Service Quality, UK Essays, [Online], Available: https://www.ukessays.com/essays/marketing/definition-of-service-quality-marketingessay.php?vref=1,[Accessed: 12-Oct-2018].

[7] A. Parasuraman, V. A. Zeithaml, and L. L. Berry 2009, A Conceptual Model of Service Quality and Its Implications for Future Research, Vol. 49, No. 4, pp. 41-50

[8] Fitriansyah and I. Harris, 2018, Pengukuran Kepuasan Pengguna Situs Web Dengan Metode End user computing satisfaction (EUCS), " Query Jurnal Sistem Informasi, Vol. 2, No. 1, pp. 1-8.

[9] Chin, C. 2002, Student-Generated Questions: Encouraging Inquisitive Minds in Learning Science, Teaching and Learning, Vol. 23, No. 1 p. 5947.

[10] Suzanto, B., Sidharta, I. 2015, Pengukuran End-User Computing Satisfaction Atas Penggunaan Sistem Informasi Akademik, Jurnal Ekonomi, Bisnis \& Entre preneurship, 9(1), 16-28.

[11] CLI Rana Nabilla Dr. Drs. Zaki Baridwan, Ak., M.Si., CA., CPA., 2013, Analisis Kesesuaian Siklus Pendapatan E-Commerce Aplikasi Belanja Online Berdasarkan Model End User Computing Satisfaciton (Eucs)"

[12] Sugiyono. 2014, Metode Penelitian Kuantitatif, Kualitatif dan R\&D, Alfabet, Bandung.

[13] Danial, E, \& Warsiah. 2009, Metode Penulisan Karya Ilmiah, Laboraterium Pendidikan Kewarganegaraan, Bandung.

[14] Rao, Purba. 2006, Measuring Consumer Perception Through Factor Analysis, The Asian Manager (February-March)

[15] Sugiyono. 2011, Metode Penelitian Kuantitaif Kualitatif dan $R \& B$, Alfabeta, Bandung. 
[16] Kristanto, Y. D. (n.d.). Bab II Estimasi Nilai Parameter (hal. 29-81).

[17] Suryawan, M. B., \& Prihandoko, P. 2018, Evaluasi Penerapan SIAKAD Politeknik Negeri Madiun Menggunakan Pendekatan TAM dan EUCS, Creative Information Technology Journal, 4(3), 233.

[18] Meyliana; Henry Antonius E. W.; Stephen W. Santoso. (n.d.), Kepuasan Pengguna Terhadap Lms Binusmaya: Perspektif Implementasi Crm pada Institusi Pendidikan Untuk Karakteristik Layanan. 1, 993-1003.

[19] Saputra and D. Kurniadi, 2019, Analisis Kepuasan Pengguna Sistem Informasi ECampus Di Iain Bukittinggi Menggunakan Metode Eucs, Jurnal Vokasional Teknik Elektronika dan Informatika, Vol. 7, No. 3, pp. 58-66. 